\title{
Investigating the Impact of External Debt on Economic Growth: A Case Study of Pakistan
}

\author{
IRUM SAJJAD \\ MS Scholar, Department of Economics \\ Abdul Wali Khan University Mardan, KP-Pakistan \\ MUHAMMAD BILAL \\ MS Scholar, Department of Economics \\ Abdul Wali Khan University Mardan, KP-Pakistan \\ DR. MUHAMMAD AZAM KHAN \\ Associate Professor, Department of Economics \\ Abdul Wali Khan University Mardan, KP-Pakistan
}

\begin{abstract}
This article is an attempt to evaluate the effect of external debt on economic growth for Pakistan during the period of 1980-2016. The Augmented Dickey Fuller (ADF) test is used for determining stationarity, whereas the ADF test results exhibit that the variables used found arestationary at 1st difference. The empirical results indicate that external debt and total debt service have deleterious and statistically significant impacts on GDP growth rate. The other explanatory variables namely human capital by life expectancy, exports, and Foreign Direct Investment (FDI)reveals significantly positive significant influence on GDP growth rate. Appropriate policy should be adopted by the policy makers to reduce external debt, increase volume of exports and enhance more foreign investment, it will boost economic growth in the country.
\end{abstract}

Keywords: Economic growth; external debt; exports; Pakistan

\section{Introduction}

The external debt burden is a well-known phenomenon for the developing countries and can be called as a common characteristic of the fiscal sector of the economies. If the rate of national saving is low then the country will go toward borrowing loans to stabilize the economic growth, that's why economies tends to take external loans. Pakistan is also in one of those developing nations which have a higher debt rate burden. According to the reports of the World Bank 2000-2001, Pakistan is in the class of highly indebted nations (HINs); because Pakistan's current and the future debt position is really grim (Ali \& Mustafa, 2012).Gross external debt, at the any given time period, is the prominent measure of those real current, and not the contingent, liabilities that postulate the payments of interest and mainly by the debtor at some stage in the future which are billed to nonresidents of the economy (World Bank, 2015). According to the World Bank (2015) description of external debt "debt owed toward non-resident repayable in provisions of the foreign currency, goods and services, external debt might be in the longer run debt (public and publicly guaranteed debt also private non-guaranteed debts) and may be short term debts (commercial debts and International Monetary Fund (IMF) loans)". Economic 
development mentions to a gain in the market value of goods and services which are produced by a nation or a percent rate of increase in the real GDP. Generally, economic growth and the Economic development are inter-convertible. But in real condition, economic growth brings up to an increase in the earning of the households of the country or an addition in the per capita income, while economic development is betterment in the living standard of a country. It is highly significant to understand the progression of public debt and economic growth. Public debt may be inside or outside both is counted as a source of financing government deficit or to carry out its economic or social goals, particularly to fill the gap among the saving and investment.

In a study by Rostow (1960) build up an Economic growth model .That model is depend upon five stages which involves traditional civilization, Preconditions for take-off, Take-off, compel to maturity and the Age of high mass expenditure. Rostow's model is one of the most applicable growth models. The connection among government debt and growth is yet uncertain. There is no reasonable contention between the economists that weather financing the stateoutlay through external debt is good, horrible or unbiased concerning investment and growth in condition. The classical economist contended that public debt is a load to the community and in the longer run state debt depress the investment. The neoclassical economist views that the public debt is destructive for the economic development though in the Ricardian views government debt is regarded as the same to future tax (Barrow, 1974).According to Todaro (1988) "preceding to earlier 1970s the external debt of the developing nations were primarily little and the official fact, majority of the creditors being overseas governments and global financial institutions offer loans for the developing projects".

In research thesis "Economic development in the cross section of countries" that the growth rate of the per capita GDP is definitely related with the human capital. The nations of a high human capital will be having the high physical investment to the GDP .The Economic development were negative identified to government consumption and irrelevantly identified with public investment. Growth rate are positively identified with political constancy while inversely identified with market distortions (Barro, 1991). In fact most of the economic theories mention an adverse result of state debt on economic growth, while few hypotheses also recommend a satisfactory enhancement in the economic improvement (Boboye \& Ojo, 2012). They advocate that the debt might be used in the productive investment with a rate of return which is higher than interest rate of the debt that is borrowed. Amassing external debt by the large number of the developing nations has made important issues for those people who are making economic policies. In order to raise the instability of the fiscal deficit and non-accessibility of the resources, public debt is the primary source to fill up the hole. As per the Keynesian hypothesis a specific amount of external debt to remove the gap of the fiscal deficit will lead to ascent in the economic development of the economy, while the surplus debt for longer timeframe will lead to unfavorably impact to the growth rate of the economy (Jebran et al., 2016).The Governments of developing countries use public debt as a major tool to finance their expenditures. Economic theories tell us that proper and efficient utilization of resources is the most reliable way to fuel the economic growth. However, poor utilization of the public debt would restrict national economic development and create the prevalent curse for the economy (Lotto \& Mmari, 2018). 
Some of the research workers conducted that there is the negative impact of external debt on the output growth rate, where a massive amount of interest rate should be paid for, while there is not such an extreme impact of domestic debt, because in the domestic debt just hands are changed while the debt are remaining within the boundaries. If we study the example of low income nations like Pakistan has constrained recourses mainly depending on the remittances, foreign aid and the public debt. Its GDP is USD 283.7 Billion in 2016 and has an aggregate debt of USD 229.141billion in 2017. Recently according to estimations the domestic debt of Pakistan is USD139.925 billion while Pakistan's External debt is USD 47.933 billion in March 2017. Most creating nations like Pakistan where every government borrowed billions of dollars to uplift their people from poverty. In case of Pakistan, per capita income is less than per citizen indebtedness as every government relay on public debt to spanning government financing gap (SBP, 2017). As Pakistan is developing country it greatly rely on external debt for economic activities so each and every government of Pakistan borrows billions of dollars. External Debt and Liability (EDL) stock provisionally stood at USD91 billion at end February 2018, out of which external public debt was USD69.3 billion, revealed the Economic Survey of Pakistan 2017-18. Figure 1 show trend in Pakistan external and domestic debt.

Figure 1: Trend in Pakistan external and domestic debt

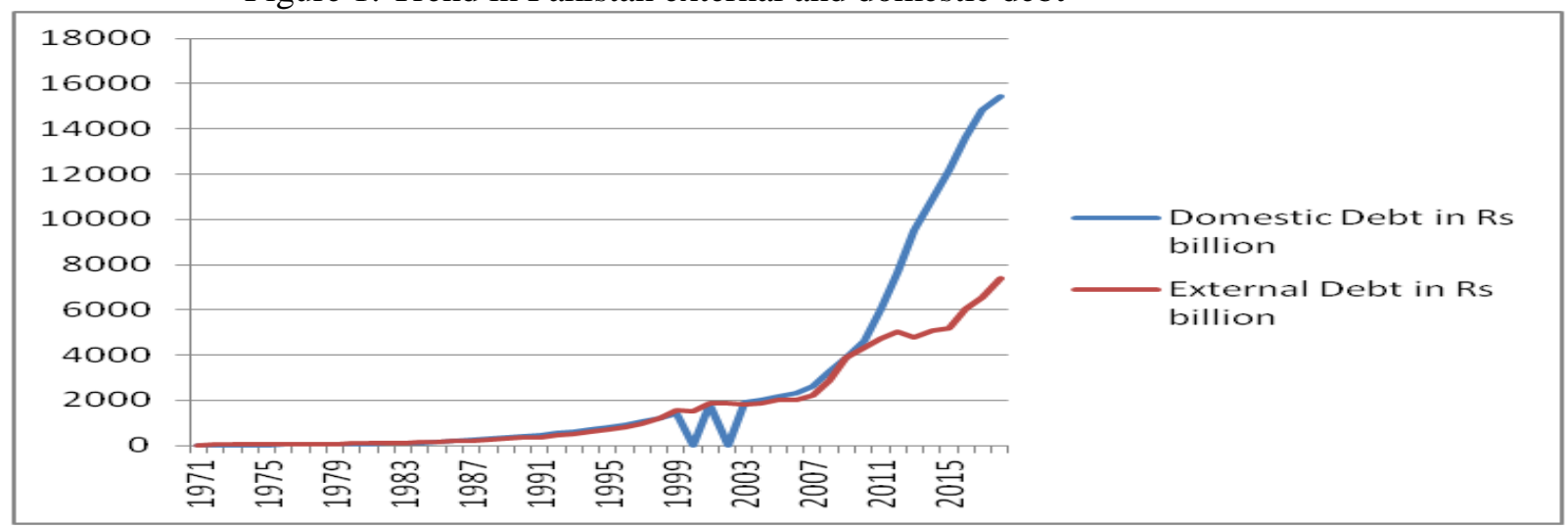

Source: Economic Survey Pakistan (2017-18)

It is to identify the last couple of years Pakistan entirely depends on public debt to run up the economic performance. But the result is not satisfactory in Pakistan. The Economic growth is dormant while the public debt is at a disturbing position. Figure 1 reveals that it is occurred an increase in the public debt from 17381 billion Rupees in 2015 to 22820 billion Rupees in 2018(Economic Survey of Pakistan, 2017-18).

To address the difficulties of the economic growth and the diminishment in the public debt of Pakistan this work will help to resolve the debt burden and its effects on the economy. The investigations and suggestions will help the policy makers to take some capable steps in the correct utilization of the resources and these debts so that we get better result. The broad objectives of this study is to examine the effect of external debt on the aggregate output by GDP growth rate of Pakistan, to find out the significant effect of external debt upon economic growth of Pakistan, and to investigate the impact of the external debt servicing on an economic growth.

This paper consists of 5 sections. Section 1 presents introduction and background of the study along with the data of external debt of Pakistan. Section 2 consists of previous theoretical and empirical studies. Section 3 highlights the methodology and data description. Section 4 deals with study results and its interpretation and the last 
section is section 5 which conclude the paper and provide best policies and recommendations for the mention issue.

\section{Literature Review}

Various studies have been carried out to analyze the link between foreign debt and growth of country by utilizing different econometric models and statistical tools to classify and authenticate the relationship. Some studies shows significant negative relationship and some could not be able to show significant results. Different studies differently linked economic growth and external debt, for instance, Borenzstien (1990) forwarded the study and concluded that the situation in which a debtor country gets a very small amount of benefits from repayment to any extra investment because of debt services obligation. Cunningham (1993) studied the connection between various sixteen intemperate debt nations and reasoned that the debt load is negatively affects upon the economic development, as a result of the effect on the productivity of the labor and capital. Also Afxentiou (1993) having a similar judgments for the twenty developing nations with negative effects of the public debt upon the economic growth. Krugman (1988) suggested the debt overhang a situation that the repayment of foreign debt declines contractual values of debt.

The study of Shabbir (2013) concluded from the studies on growth for 24 nations for the years 1976 up to 2003 observes that there is negative liaison among public debt and the growth. Azam and Khan (2008) also suggest that external debt has adverse effect on growth of Pakistan. Hassan and Butt (2008) using the ARDL approach of co-integration, and the researchers didn't suggest any indication about the influence of external debt on growth, while concluded that labor force and trade shows positive response to economic growth in case of Pakistan during 1975 to 2005. Adosla (2009) detects that debt services payment presented the negative effect on economic growth in case of Nigeria. Carmen and Kenneth (2009) contended in their research work named by Growth in a season of debt that a relationship among government debt and the real GDP growth is light. Second point is that developing market faces the lower thresholds for the external debt. Third point there is zero connection between inflation and the public debt for propel economies. Malik et al. (2010) investigated the relationship among external debt and economic growth of Pakistan for the years 1972-2005, the study showed that external debt and debt servicing are not positively, but negatively significant with economic growth. The effect of the high and rising debt on the economic growth by Checherita and Rother (2010) examined for twelve nations (Belgium, France, Finland, Austria, Germany, Spain, Ireland, Portugal, Luxembourg, Netherlands, Italy, \& Greece) informational index was for a long time beginning from 1970.They explore non-linear effect of the debt on development. They presumed that the debt to GDP proportion adverse affects on the economic development in long run.

In an investigation of effect of the public debt upon the economic development of Pakistan by Akram (2011) amongst (1972 -2009) applied the Auto Regression Distributed Lag (ARDL) method. The researcher resolution was that the public external debt is having a negative association with the per capita GDP and verifying to the actuality of the debt overhang impact. Imran and Anwar (2012) studied effect of the public debt and economic development in Pakistan applying the OLS method by utilizing dataset for (1972-2010). The researchers accomplished that both kind of the external and domestic debt are having the negative role in a real per capita growth rate of income. Azam et al. (2013) carried out study for the Indonesian economy and 
observes that debt taken from other countries have inverse effect on the growth of Indonesian economy. Panizza and Presbitero (2013) analysis the relationship between public debt and economic growth of advanced economies the estimated results was ambiguous because high level of public debt has negative effect on the long run economic growth. Aminn et al. (2013) examined Algeria economy utilizing the OLS technique and discover that the external debt is having the negative effect on the economic development however the domestic debt has a positively effects the growth.

In case of African countries, the study of Azam and Gavrila (2015) investigate the influence of incoming external capital on the growth of African countries. Balanced panel data is used for the period of 1977-2013 of ten African countries. For the estimation of result Hausman test is used. Result reveal that capital inflows encouraged economic growth while external debt discourage growth. The study of Siddique et al. (2015) recommends that in the short-run as well as in long-run, decrease in debt stock would have substantially improved the growth performance of the indebted countries. Asghar (2016) examined the effect of external debt on the economic performance of Pakistan uses time series data for the period of 1986-2015. The least squares method is used for descriptive analysis, results shows that the huge amount of number of GDP of country is backed by external debt.Azam (2016) observes that weak governance as well as external debt and foreign aid havedestructive significant influence on the growth, while FDI and remittances have significant positive impact on the economic performance of 20 OIC countries during 1986-2012. The study of Khan et al. (2017) suggest that human capital has substantial positive effect on aggregate output.

In case of Sri Lanka, the study of Akram (2017) using data from 1975 to 2014and applied ARDL model, the results show that public external debt contribute in the economic growth of the country, while debt servicing has negative relationship to per capita GDP and investment.Mousa and Shawawreh (2017 ) worked on economy of the Jordon during (2000-2015) utilizing the least square technique and the Regression model to catch the effects of the debt upon economic development and discovered that the aggregate public debt is negatively affects the economic development. Lotto and Mmari (2018) examined impact of domestic debt on the economic growth of Tanzania for the period of 1990 to 2015 using OLS technique and finds that the domestic debt is having a negative and insignificant effect on the economic growth of Pakistan.Kharusi and Ada (2018) investigate the relationship between the government external borrowing and economic growth of Oman. Uses time series data for the period of 1990-2015 and applied auto regressive distributed lag co integration approach. The result reveals negative and significant effect of public debt on the Oman's economy performance.

Theabovementioned literature reveals that Krugman (1988), Afxentiou (1993), Shabbir (2013), Checherita and Rother (2010), Akram (2011), Imran and Anwar (2012), Azam (2016),Mousa and Shawawreh (2017) andKharusi and Ada (2018) studiesshow that there are destructivelink between external debt and growth.Lotto and Mmari (2018) study reveals that domestic debt has negative effect on growth, whileAminnet al (2013), shows that domestic debt has a positive effect on growth. Hassan and Butt (2008) finds that external debt has inverse effect on growth of Pakistan and concluded that labor force and trade shows positive response to 
economic growth of Pakistan. Akram (2017) study observes that public external debt has positive relationship with growth rate in Pakistan.

\section{Data and Methodology}

The data set used in this research paper consists of data covering period of 1980 to 2016, which is the time series annual and secondary data. The data has been collected from the World Development Indicators (WDI) (2018), World Bank. GDP is the dependent variable although export, FDI, human capital as a proxy life expectancy has been used, total debt service, capital formation and the external debt servicing are independent variables.

\subsection{Model specifications}

The following multivariate regression model is used in this study to verify the impact of foreign debt on the economic growth together with some other macro variables like the exports, capital formation, foreign direct investment and the life expectancy as a control variables.The estimating equation for this study is similar with Ali and Mustafa (2012), Azam and Khan (2011), Khan et al. (2015), Khan et al. (2016), Bahattab et al. (2016), Azam and Khan (2018), Rehman et al. (2018), Azam (2018), and Lotto and Mmari (2018) and can be written as below:

$Y t=b o+b 1 T D S+b 2 E D S+b 3 L E+b 4 C F+b 5 F D I+b 6 X+\mu$

Where,

$\mathrm{Y}=\mathrm{GDP}$ growth (\% annual growth)

TDS $=$ Total debt service $(\%$ GNP)

$\mathrm{ESD}=$ External debt servicing (total USD)

$\mathrm{LE}=$ Life expectancy ${ }^{1}$ at birth, total (years)

$\mathrm{CF}=$ Gross capital formation (current USD)

FDI $=$ net Foreign direct investment (current USD)

$\mathrm{X}=$ Exports value (Current USD)

$\mu=$ Error Term (error term is used for the missing variables)

In Eq. (1) external debt servicing and total debt servicing are expected to be negatively related with economic growth while capital formation, export and FDI expected to be positively related with growth of Pakistan.

\section{Results and Discussion \\ 4.1 Regression diagnostic tests \\ 4.1.1 Stationarity of data}

A unit root test was use to check data is stationary or not, this is because when data is non stationary it may lead to inefficient and biased results which would not be accurate for policy making. For this reason Augment Dickey - Fuller (ADF) test was run on each variable to check whether it is stationary or not. The decision will be based on P- values if significant then null hypothesis rejected and if insignificant then there is non stationarity problem and results are given in Table 1.

The ADF unit root test results are presented in Table 1, which indicates that all the seven variables when tested for unit root first with intercept and then with intercept and trend become was non stationary at level but when they are checked again at first difference they become stationary that suggested the use of Johansen Co integrated test for long run association. Each and every variable was checked for Unit root test and find that all the seven variables are non-stationary at level with

\footnotetext{
1 "Human capital, it consists of the skills and knowledge of particular workers" (life expectancy used as a proxy of human capital")
} 
intercept and with intercept and trend. Likewise, all the seven variables are found stationary at first difference with intercept and intercept and trend. $\mathrm{P}$ values are statistically significant at First difference 1(1).

Table 1: Results of ADF Test for Stationarity

\begin{tabular}{|c|c|c|c|c|c|}
\hline \multicolumn{3}{|c|}{ Include Intercept Only } & \multicolumn{3}{|c|}{ Include Intercept and Trend } \\
\hline \multirow{2}{*}{$\begin{array}{l}\text { Variables } \\
\text { GDP }\end{array}$} & Test Statistics & CriticalValue & Test Statistics & CriticalValue & \multirow{2}{*}{$\frac{\text { Result }}{1(1)^{*}}$} \\
\hline & 0.658776 & -2.945842 & $-1.455351[0]$ & -3.540328 & \\
\hline & $-5.496389[0]$ & -2.948404 & $-5.841090[0]$ & -3.544284 & $1(1)^{* *}$ \\
\hline \multirow[t]{2}{*}{ TDS } & $-1.285722[0]$ & -2.945822 & $-2.567794[0]-$ & -3.540328 & $1(1)^{*}$ \\
\hline & $-5.760619[1]$ & -2.951125 & $6.340456[1]$ & -3.548490 & $1(1)^{* *}$ \\
\hline \multirow[t]{2}{*}{ EDS } & $-2.094361[0]-$ & -2.945842 & $-3.193669[0]$ & -3.540328 & $1(1)^{*}$ \\
\hline & $8.441103[0]$ & -2.948404 & $-8.432819[0]$ & 3.544283 & $1(1)^{* *}$ \\
\hline \multirow[t]{2}{*}{ LE } & $-5.672944[9]$ & -2.976263 & $-0.668691[9]$ & -3.587527 & $1(1)^{*}$ \\
\hline & & & $-6.471166[8]$ & -3.587527 & $1(1)^{* *}$ \\
\hline \multirow[t]{2}{*}{$\mathrm{CF}$} & $-0.135091[0]$ & -2.945842 & $-1.995485[0]-$ & -3.540328 & $1(1)^{*}$ \\
\hline & $-5.472663[0]$ & 2.948404 & $5.457586[0]$ & -3.544284 & $1(1)^{* *}$ \\
\hline \multirow[t]{2}{*}{ FDI } & $-2.180223[0]$ & -2.945842 & $-2.750681[0]$ & -3.540328 & $1(1)^{*}$ \\
\hline & $-7.953621[0]$ & -2.948404 & $-7.841593[0]$ & -3.544284 & $1(1)^{* *}$ \\
\hline \multirow[t]{2}{*}{$X$} & $-1.177552[0]$ & -2.945842 & $-1.688451[0]$ & -3.540328 & $1(1)^{*}$ \\
\hline & $6.339281[0]$ & -2.948404 & $-6.375680[0]$ & -3.544284 & $1(1)^{* *}$ \\
\hline
\end{tabular}

Note: Figures in square brackets besides each statistics represent optimum lags selected using the Schwarz info criterion.2Figures in Parentheses are first difference of the variables, * represents result when intercept is included only $\imath^{*}$

* show results when intercept and trend is included.

\subsubsection{Johansen Co integration test}

Table 2 represents the result of Johansen co integration that the assumption of no co integration amongst the variables of model

Test Assumption: No deterministic trend in the given data.

Lag interval in first difference (1 to 1 ).

Table 2 shows the result of Johansen Co integration that is used for long run relationship between the variables used in the model. For the test the assumption of no deterministic trend was made.The ideal rule is that when the P-value is less than $5 \%$ critical value we reject null hypothesis.It is clear from the table that from $4^{\text {th }}$ row the probability value is 0.1279 which is greater than $5 \%$ so we cannot reject the null hypothesis of no co integration meaning that we accept that the variables used in the model have long run association or the variables moves together in the long run. So the result indicates at most 3 co integration.

Table 2: Johansen Co integration test results

\begin{tabular}{llllc}
\hline Hypothesized No. of CE $\begin{array}{l}\text { Eigen } \\
\text { Value }\end{array}$ & \multicolumn{4}{l}{ Trace Statisti $5 \%$ critical vall Prob.** } \\
\hline None * & 0.7820 & 173.3173 & 125.6154 & 0.0000 \\
& 24 & & & \\
At most $1 *$ & 0.6947 & 119.9994 & 95.75366 & 0.0004 \\
& 39 & & & \\
At most 2* & 0.6349 & 78.46882 & 69.81889 & 0.0087 \\
& 68 & & & \\
At most 3 & 0.4812 & 43.19683 & 47.85613 & 0.1279 \\
\hline
\end{tabular}




\begin{tabular}{|c|c|c|c|c|}
\hline & 17 & & & \\
\hline At most 4 & $\begin{array}{l}0.3130 \\
32\end{array}$ & 20.22737 & 29.79707 & 0.4076 \\
\hline At most 5 & $\begin{array}{l}0.1302 \\
89\end{array}$ & 7.086019 & 15.49471 & 0.5677 \\
\hline At most 6 & $\begin{array}{l}0.0609 \\
29\end{array}$ & 2.200237 & 3.841466 & 0.1380 \\
\hline
\end{tabular}

\subsection{Regression Results}

The Least Squares method results are given in Table 3. The overall results found to be acceptable based on signs of coefficients, $R^{2}$ value, ad. $R^{2}$ values, test statistics and F ratio. The adj. $R^{2}$ value is $98 \%$ which shows that $98 \%$ variation in dependent variable which is economic growth explained by explanatory variables those are capital formation, exports, net FDI inflows, life expectancy, total debt servicing and external debt servicing and remaining $2 \%$ variation is due to other variables which is explain by the error term. These results show that all explanatory variables jointly influence the dependent variable that is economic growth. The results shows that model is not forged because adj. $\mathrm{R}^{2}$ square value is high and value of Durbin Watson is 1.74 which is near to 2 so that shows that there is no autocorrelation problem. Hence the significant of overall model can be tested by the value of F-Statistic and its corresponding probability value. It is evident from Table 3 that total debt service and external debt servicing have negative impact of economic growth (annual GDP growth rate) and statistically significant at $10 \%$ level of significance.Net FDI and exports and life expectancy have positive and statistically significant impacts on economic growth during the period of 1980-2016. The empirical results of this study are in line with Malik et al. (2010), Azam et al.(2013), Bakar et al. (2014),Haseeb et al. (2014), Bahattab et al. (2016), Muhammad et al. (2017), Mousa and Shawawreh (2017), Lotto and Mmari (2018), and Kharusi and Ada (2018).

Table 3: Least Squares results

\begin{tabular}{lccc}
\hline Variables & Coefficient & Standard deviation & t-ratios \\
\hline Constant & -4.226 & 2.672 & 1.581 \\
TDS & $-0.167^{* * *}$ & 0.089 & 1.865 \\
EDS & -0.043 & 0.093 & 0.460 \\
LE & $0.105^{* * *}$ & 0.049 & 2.118 \\
CF & $0.783^{*}$ & 0.138 & 5.653 \\
FDI & $0.214^{* *}$ & 0.092 & 2.331 \\
$\mathrm{X}$ & $0.198^{* * *}$ & 0.103 & 1.928 \\
$\mathrm{R}^{2}=98.4 \%$ & \multicolumn{3}{c}{ adj. $\mathrm{R}^{2}=98.0 \%$} \\
F-Statistics $=2.574$ & \multicolumn{2}{c}{ Prob $(F-$ ratios $)=0.038$} \\
D- Watson ratios $=1.74$ & Note: Asterisks $* * *$ and $* * *$ show significant at 1,5 and $10 \%$ level.
\end{tabular}

\section{Summary, conclusion, and recommendations}

Many countries including Pakistan is getting loan from the other countries and international organization due to the lack of finance/money, while money is undeniably required for the national economic development. Therefore, this study analyses the effect of external debt on GDP growthrate. For empirical analysis time 
series data is used covering period of 1980 to 2016. Johansen Co-integration test was used as an analytical technique to authenticate association between external debt and economic growth. An addition, other explanatory variables that are life expectancy, capital formation and net foreign direct investment inflows are also used. The results are found statistically significant and carry expected signs according to our hypothesis. External debt, total and debt servicing have negative impact and statistically significant, as it was expected and other variables namely human capital measured by life expectancy, exports, and incoming FDI have statistically progressiveinfluence on the aggregate output by GDP growth rate. The main findings of this paper are that external debt damp down aggregate output, while on the other hand export augment Pakistan economy during the study period. These results supports many previous studies that if external debt is not properly utilize and manage it will become huge burden on the economy. This is not only true for the Pakistan but also for the rest of the world.

Empirical results suggest some policy measure. For sustainable development of Pakistan it is suggested to reduce negative external debt shocks by implementing active management policies. The best policy for this purpose government needs to use domestic debts instead of external debts. Other policies are that borrow loan with long maturity and with fixed interest rate and use external debts in productive projects so from projects earning government can easily payback this amount to lenders.In case of Pakistan the basic objective of the external debt is to boost development activities. This could also be possible by increasing exports earning through export led-growth policies. Different guide lines, monitoring system should be adapted to controlled external debt at sustainable level. Different policies like fiscal and monetary policy and macro variables like inflation, exchange rate policy, pricing policy and interest rate policy should be strengthen in order to spur confidence of foreign and as well as local investors. Due to political instability and terrorism Pakistan faces a lots of problems in which the prominent problem is that Pakistan has lost its investors' confidence. Now it's time to get back investors confidence and they invest in our country due to which Pakistan can get rid of heavily reliance on external debt. Pakistan can overcome this problem by implementing right policies but will need sort of support through debt relief initiatives.

\section{References}

Adosla, W. A. (2009) Debt servicing and economic growth in nigeria: an empirical investigation. Global Journal of Social Sciences, 8 (2), 1-11.

Afxentiou, P. C. (1993). GNP growth and foreign indebtedness in middleincome developing countries. International Economic Journal, 7(3), 81-92.

Ali, H., Farooq, F., \&Mumtaz, N. (2016). Trade openness, external debt and growth nexus in Pakistan: empirical evidence from ARDL modelling approach \& co-integrationcausality analysis. Review of Economics and Development Studies, 2(2), 93-102.

Ali, R., \& Mustafa, U. (2012). External debt accumulation and its impact on economic growth in Pakistan. The Pakistan Development Review, 79-95.

Akram, N. (2017). Role of Public Debt in Economic Growth of Sri Lanka: An ARDL Approach. Pakistan Journal of Applied Economics, 27(2), 189-212.

Akram, N. (2011). Impact of Public Debt on the economic growth of Pakistan. The Pakistan Development Review, 599-615. 
Asghar, M. S. (2016). The effect of external debt in the economic growth of Pakistan. ABC Journal of Advanced Research, 5(2), 71-76.

Azam, M. (2016). Does governance and foreign capital inflows affect economic developmentin OIC Countries?. Journal of Economic Cooperation and Development, 37(4), 21-50.

Azam M, (2018). Inequality and economic growth in Asia and the Pacific region. African and Asian Studies (forthcoming)

Azam, M., Emirullah, C., Khan, A. Q., \&Prabharker, A. C. (2013). The role of external debt ineconomic growth of Indonesia-A Blessing or Burden. World Applied Science Journal, 25(8), 1150-1157.

Azam, M., \& Khan, A. (2008). Qualitative analysis of the external debts in Pakistan. Abasyn University Journal of Social Sciences, 2 (1), 1-5

Azam, M.,\& Khan, A. (2011). Impact of public debt on foreign direct investment in Pakistan: a quantitative approach. Journal of Finance and Economics, 3(8), 42254231

Azam, M. \& Khan, S. (2018). Inflation and the economic growth: evidence from Five Asian Countries. Pakistan Journal of Applied Economics, 28(2), 235-252

Bahattab, A. S., Azam, M.,Gavrila, L., \& Emiruallah, C., (2016). Foreign capital inflows, institutional factors and economic growth: Evidences from Republic of Yemen. Journal of Applied Economic Sciences, 5(43), 811-816

Bakar. N. A. Haseeb, M., \& Azam, M., (2014). The nexus between education and economic growth in Malaysia: cointegration and Toda-Yamamoto causality approach. Actual Problems of Economics, 12(162), 131-141

Boboye, L., \& Ojo, M. (2012). Effect of external debt on economic growth and development ofNigeria. International Journal of Business and Social Science, 3(12), 67-87

Checherita, W. C., \& Rother, P. (2012). The impact of high government debt on economic growth and its channels: An empirical investigation for the euro area. European Economic Review, 56(7), 1392-1405.

Cunningham, R. T. (1993). The effects of debt burden on economic growth in heavily indebted developing nations. Journal of economic development, 18(1), 115-126.

Domodar,,N.G., (2003). Basic Econometrics, $4^{\text {th }}$ Edition, McGraw-Hill International Edition.

Economic Survey of Pakistan (2017-18), Government of Pakistan, Ministry of Finance, Islamabad.

Haseeb, M., N.H. Hartani, N.A.A. Bakar, Azam M. \& S. Hassan, (2014). Exports, foreign direct investment and economic growth: Empirical evidence from Malaysia (1971-2013). American Journal of Applied Sciences, 11: 1010-1015.

Imran, R.S.,\& Anwar, T. (2012). Public debt and economic growth in Pakistan: A time series analysis from 1972 to 2010. Academic research international, 2(1), 535.

Khan, S.,Azam, M., \& Chandra, E., (2016). Import demand, income elasticity and growth rate in Pakistan: the impact of trade liberalization. Foreign Trade Review, 51(3), 1-12

Khan, A.Q., Azam, M., Samsi, A., Emirullah, C., \& Usman, M. (2015). Impact of defense spending on unemployment in five countries from Asia.Corporate Board: Role, Duties \& Composition, 11 (3), 117-129

Kharusi, S. A., \& Ada, M. S. (2018). External debt and economic growth: the case ofemerging economy. Journal of Economic Integration, 33(1), 1141-1157. 
Krugman, P. (1988). Financing vs. forgiving a debt overhang. Journal of development Economics, 29(3), 253-268.

Lotto, J., \&Mmari, C. T. (2018). Domestic Debt and Economic Growth in Tanzania. Journal of Economics and Management Sciences, 1(1), 207-207.

Malik, S., Hayat, M. K., \& Hayat, M. U. (2010). External debt and economic growth: Empiricalevidence from Pakistan. International Research Journal of Finance and Economics, 44(44), 1450-2887.

Mohanty, A. R., \& Mishra, B. R. (2016). Impact of Public Debt on Economic Growth: Evidencefrom Indian States. Vilakshan: The XIMB Journal of Management, 13(2), 55-67

Mousa, T. A., \& Shawawreh, A. M. (2017). The Impact of Public Debt on the Economic Growthof Jordan: An Empirical Study (2000-2015). Accounting and Finance Research, 6(2),1-14.

Muhammad, A.,M., Khan, A. Q., \&Bakhtyar, B., (2017). Surveying sources of economic growth: empirical evidence from Malaysia. Problems and Perspectives in Management, 15(4), 114-123

Public debt economic survey of Pakistan (2018)

Panizza, U., \&Presbitero, A. F. (2013). Public debt and economic growth in advanced economies: A survey. Swiss Journal of Economics and Statistics, 149(2), 175-204.

Shabbir, S. (2013). Does external debt affect economic growth: evidence from developing countries. SBP Working Paper Series, No.63

Rehman, Z., Tariq, M., \& Azam, M., (2018). The role of human capital in economic development in the selected Central Asian countries. The Dialogue, XIII(03), 235-244

Rostow, W. W. (1960). The Story of Economic Growth: A Non-Communist Manifesto. Cambridge University Press.

World Development Indicators (2018), The World Bank 